\title{
Esquema mental de reciprocidade e influências sobre afetividade no trabalho
}

\author{
Mirlene Maria Matias Siqueira \\ Universidade Metodista de São Paulo
}

\begin{abstract}
Resumo
Noções sociológicas de troca social têm marcante influência sobre como são interpretadas relações entre empregado e organização, destacando-se o papel exercido pela norma de reciprocidade. O presente estudo foi desenvolvido com o objetivo de ampliar a compreensão psicossocial de três conceitos: percepção de suporte, percepção de reciprocidade e comprometimento normativo. Apresentam-se hipóteses sobre sua integração a um esquema mental de reciprocidade e sua influência sobre dois critérios afetivos: satisfação no trabalho e comprometimento organizacional afetivo. Participaram do estudo 483 empregados de empresas particulares e públicas da Grande São Paulo. Os resultados do estudo atestaram a pertinência de se considerar os três conceitos analisados como integrantes do esquema mental de reciprocidade bem como evidenciaram a capacidade deste esquema explicar proporções significativas da variância de dois critérios afetivos. Percepção de suporte organizacional revelou-se o componente cognitivo com maior poder de influência sobre satisfação no trabalho e comprometimento afetivo.
\end{abstract}

Palavras-chave: esquema mental de reciprocidade; percepção de suporte organizacional; satisfação no trabalho; comprometimento organizacional afetivo; troca social.

\begin{abstract}
Mental reciprocity's scheme and its influence on affectivity at work. Sociological notions of social exchange have outstanding influence on the interpreted relations between employee and organization, being of relevance the role performed by the norm of reciprocity. The present study was developed with the objective of extending the psychological understanding of three concepts: perception of organizational support, perception of organizational reciprocity, and normative organizational commitment. Hypotheses were presented about their integration to a mental reciprocity scheme and about their influence on two affective criterions: job satisfaction and affective organizational commitment. 483 employees of private and public companies of the Great São Paulo took part in the study. The results certified the relevance of the three concepts considered as components of the mental reciprocity scheme, and demonstrated the capacity of this scheme to explain significant proportions of the variance of two affective criterions. Perception of organizational support turned out to be the cognitive component with the strongest power of influence on job satisfaction and affective organizational commitment.
\end{abstract}

Keywords: mental reciprocity scheme; perception of organizational support; job satisfaction; affective organizational commitment; social exchange.

$\mathrm{N}$ ormas sociais (Becker, 1956; Homans, 1958; Malinoviski, 1922) são princípios ideais de obrigatoriedade no convívio social, entendidas também como regras compartilhadas por um grupo para delimitar o comportamento de seus membros integrantes (Gibbs, 1989) e que correspondem a padrões culturais universais, tendendo a se concretizar e a ser transmitidas por ações regulares e previsíveis (Nova, 2000).

Têm marcantes influências sobre os estudos organizacionais concepções sobre a vida social que permitem analisar relações de troca entre indivíduo e organização (Gundlach,
Achrol, \& Mentzer, 1995; Konovsky \& Pugh, 1994; Wayne, Shore, \& Liden, 1997). Dentre elas, destacam-se as peculiaridades da troca social formuladas por Blau (1964) e a norma de reciprocidade defendida por Gouldner (1960). No campo de estudos do comportamento micro-organizacional, focalizando-se o indivíduo como unidade de análise, encontram-se diferentes conceitos psicossociais sustentados por estas amplas concepções: percepção de suporte organizacional (Eisenberger, Huntington, Hutchison, \& Sowa, 1986), comprometimento organizacional normativo (Weiner, 1982) e percepção de reciprocidade organizacional (Siqueira, 1995). 
Este trabalho tem dois objetivos. O primeiro é apresentar três conceitos do comportamento organizacional como componentes de um esquema mental de reciprocidade do empregado. O segundo objetivo consiste em oferecer evidências empíricas acerca das relações entre um esquema mental de reciprocidade e dois conceitos que representam afetividade no trabalho.

\section{Troca social}

Segundo Blau (1964), as interações de troca entre duas partes podem assumir uma dimensão econômica ou social. A troca econômica é realizada com base em um contrato em que se estipula exatamente o que será trocado entre as partes. A troca social, por seu turno, envolve oferta de "favores que criam futuras obrigações não especificadas, sendo a natureza da retribuição deixada a cargo daquele que deverá retribuir” (Blau, 1964, p. 94). Troca social estaria assentada na confiança mútua, em obrigações não especificadas gerando, entre os envolvidos, "sentimentos de obrigação pessoal, gratidão e confiança” (p. 94).

Supõe-se que o conhecimento humano sobre troca social esteja cognitivamente estruturado através da interdependência de vários esquemas mentais matriciais específicos. Numa visão cognitivista, o conhecimento pode ser representado mentalmente através de esquemas, quando "abrange uma série de conceitos inter-relacionados em uma organização significativa” (Sternberg, 2000, p. 185). Ainda segundo Sternberg, os esquemas são úteis porque, ao serem estruturados, incluem informações que podem ser aplicadas como base para interpretação de situações novas. A aplicação de esquemas já elaborados para compreender situações novas teria como função psicológica a economia cognitiva (Collins \& Quillan, 1969), princípio que permite reduzir o volume de informações necessárias, que precisam ser aprendidas, percebidas, lembradas e reconhecidas (Eysenck \& Keane, 1994), reduzindo o esforço mental e possibilitando maior agilidade no entendimento de situações novas. Aponta-se como de interesse para a discussão deste estudo o esquema mental sobre norma de reciprocidade.

\section{Norma de reciprocidade}

Tomando a máxima de Cícero como ponto de partida, segundo a qual "não há dever mais indispensável do que retribuir um favor”, Gouldner (1960) defende serem as rela- ções sociais regidas por um princípio moral, aceito universalmente e não padronizado, que define como obrigação o ato de retribuir um favor recebido. Denominado norma de reciprocidade, se assenta em duas exigências sociais básicas: (a) deve-se ajudar a quem nos ajuda e (b) não se deve prejudicar a quem nos beneficia. Mesmo sem prescrição legal, a norma é evocada em situações sociais diversas, sempre que um doador oferece ajuda, auxilia, presta um favor ou beneficia outra pessoa. A norma não prescreve como moralmente desejável a oferta de ajuda nas relações sociais, mas normatiza o comportamento do receptor, prescrevendo como obrigação moral a retribuição do benefício recebido. Portanto, as noções defendidas por Gouldner estão assentadas em dois papéis do convívio social: o papel de doador e o de receptor. Sendo papel social um conjunto de ações padronizadas que se espera das pessoas ao ocuparem posições numa interação social (Nova, 2000), entende-se que a norma de reciprocidade não só provoca a noção de débito no receptor como também leva o doador a desenvolver expectativas de retribuição por parte do receptor.

\section{Esquema mental de reciprocidade}

O esquema mental de reciprocidade, ou representação mental do conhecimento sobre a norma de reciprocidade defendida por Gouldner (1960), seria estruturado a partir do entrelaçamento de conceitos tais como: doador, receptor, retribuição, obrigatoriedade, credor e devedor. Quatro destes conceitos indicam tipos de papéis sociais (doador, receptor, credor e devedor) enquanto dois descrevem a natureza da interação (retribuição, obrigatoriedade). Com base nesta concepção cognitivista, a norma de reciprocidade seria um conhecimento social formatado mentalmente como um esquema matricial, a partir do qual são interpretadas relações sociais em contextos diversos, especialmente relações de troca social entre empregado e organização (Figura 1).

No contexto de troca social com a organização, o esquema mental de reciprocidade do empregado seria ampliado para abarcar conceitos que descrevam possíveis papéis sociais intercambiáveis de dois atores - empregado e organização: quatro papéis do empregado (doador, receptor, devedor e credor) e quatro da organização (doadora, receptora, devedora e credora). Fazem também parte do esquema as noções sobre retribuições dos dois atores e respectivas obrigatoriedades.

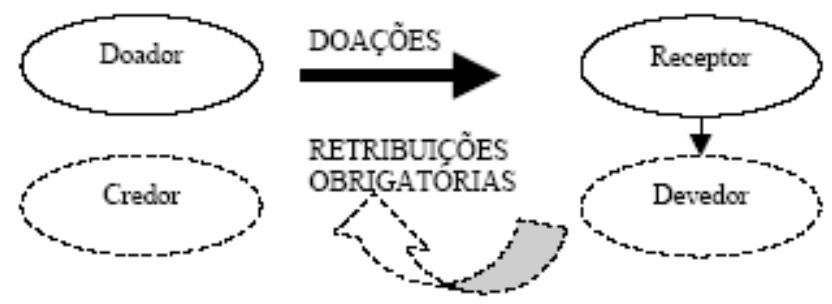

Figura 1. Esquema mental para a norma de reciprocidade. 
No campo de estudos do comportamento organizacional, noções sobre troca social, norma de reciprocidade e cognição são articuladas para sustentar diversos conceitos psicossociais. Entretanto, permanecem lacunas na concepção de alguns deles, suscitando análises que permitam aproximar ainda mais postulados da Sociologia e Psicologia Cognitiva. Um reexame de conceitos psicossociais que apresentam tais limitações em suas concepções será desenvolvido a seguir, tendo-se como foco percepção de suporte organizacional, comprometimento organizacional normativo e percepção de reciprocidade organizacional. Argumentar-se-á também a favor da integração dos três conceitos psicossociais citados acima ao esquema mental de reciprocidade nas relações sociais entabuladas entre empregado e organização.

\section{Percepção de suporte organizacional}

Em 1986, Eisenberger et al. propuseram que os empregados elaboram crenças globais sobre a extensão em que uma organização valoriza suas contribuições e cuida de seu bemestar. A este conjunto de crenças eles denominaram percepção de suporte organizacional (PSO). Para esses autores, a norma de reciprocidade de Gouldner (1960) explica o relacionamento entre empregados e organização, na medida em que empregados formam percepções genéricas sobre intenções e atos da organização a eles direcionados, a partir da observação de como os seus dirigentes praticam as políticas e os procedimentos de gestão de pessoas, atribuindo à organização características humanas e acreditando manter relações sociais com ela. Entretanto, os idealizadores de PSO não exploraram os papéis sociais representados pelos atores - empregados e organização - na relação social em que emergem crenças sobre suporte oferecido pela organização empregadora.

Para que a norma de reciprocidade seja adequadamente utilizada como base teórica social na compreensão de PSO, é necessário posicionar o empregado como receptor e a organização como doadora, especificando-se o papel de cada uma das partes como atores durante a troca social (Figura 2).

Nota-se que está sendo dada à PSO uma ampla roupagem cognitivista. Como primeiro ponto deste entendimento, supõe-se que todas as informações sobre as relações de troca social com a organização estejam reunidas em um arranjo simbólico mental que toma a forma de esquema. De acordo com esse enfoque, os conceitos de organização doadora e de empregado receptor foram derivados de um esquema mental mais amplo e matricial elaborado para o convívio social, denominado norma de reciprocidade no âmbito das ciências sociais. Doações organizacionais são entendidas como atos gerenciais que concretizam a política de gestão de pessoas no dia-a-dia da dinâmica organizacional. Nesta perspectiva, as crenças que integram PSO representam cognições sobre o quanto a organização já doou, através de suas políticas de gestão de pessoas, ou poderá doar para seus empregados no futuro. Crenças de PSO são desenvolvidas porque o empregado se coloca no papel de receptor de doações já feitas, ou de provável receptor de doações futuras da organização. Tais crenças servem para compor a identidade social do empregado nesta relação de troca social: ele identifica a si próprio como um beneficiário e a organização como uma fonte social de apoio, fortalecendo-se o conceito de PSO como um componente cognitivo do esquema mental de reciprocidade. Portanto, PSO são crenças nutridas por empregados que se posicionam mentalmente como receptores ou beneficiários de doações organizacionais durante o intercâmbio social.

\section{Comprometimento organizacional normativo}

Comprometimento organizacional, segundo Weiner (1982), compreende a internalização de pressões para ações que vão ao encontro de objetivos e metas organizacionais, levando empregados a pautar seu modo de agir em consonância com as crenças sobre o que consideram correto e moralmente aceitável. Segundo Nova (2000), normas sociais exercem um poder coercitivo através de sentimentos de obrigatoriedade, sem serem claramente compreendidas pelo próprio indivíduo as razões para alguns de seus atos. Por outro lado, violações de um dever moral geram sentimentos de culpa.

Após receber doações organizacionais e se colocar no papel de receptor, fortalecendo crenças de que a organização se preocupa com seu bem-estar e se configura como uma fonte de suporte (PSO), o empregado receptor passa a acreditar também que deva retribuir à organização de alguma forma (Figura 3). A partir de uma visão cognitivista, as crenças do empregado acerca desta dívida social para com a organização, ou seja, a obrigatoriedade de retribuir um favor, compõem o comprometimento organizacional normativo - CON.

Ao se reposicionar como devedor, o empregado também reelabora o papel social da organização nesta relação e a ela atribui o papel de credora. Tomando também neste contexto de troca social a norma de reciprocidade como um esquema mental matricial, a qual preconiza a obrigatoriedade de retri-

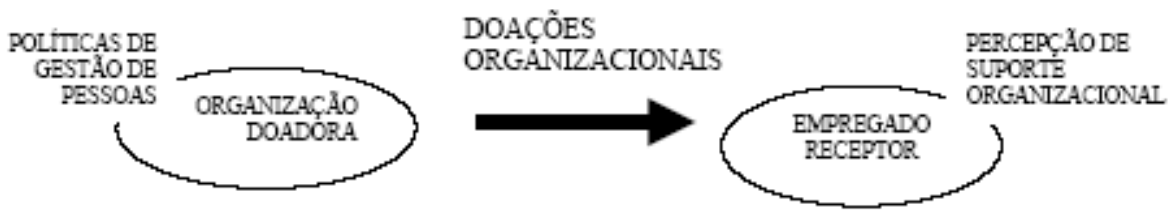

Figura 2. Percepção de suporte organizacional como crenças do empregado receptor. 


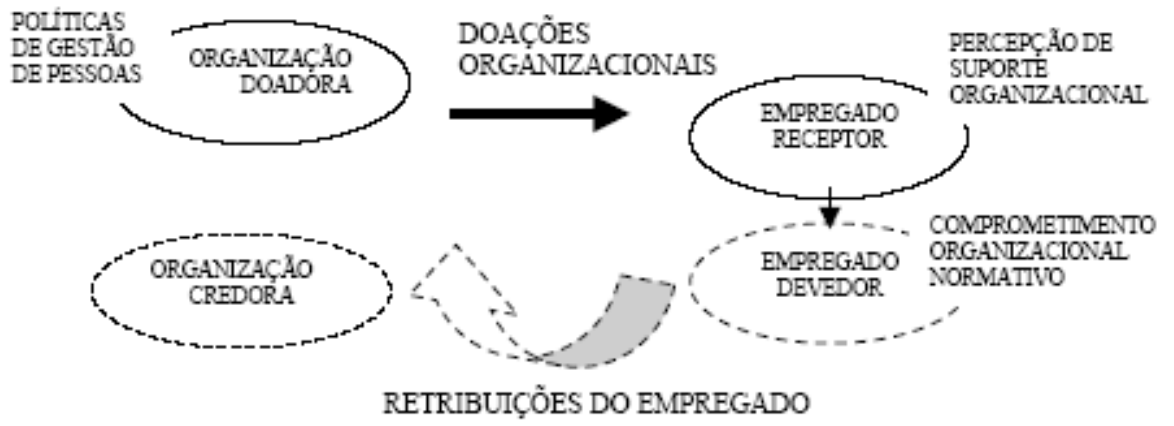

Figura 3. Comprometimento organizacional normativo como crenças do empregado devedor.

buir um favor, o empregado receptor, ao se identificar como devedor, fortalece suas crenças de débito moral para com a organização, as quais são consideradas por pesquisadores do comportamento organizacional como CON. A “concepção psicológica de CON está assentada numa esfera cognitiva, pressupondo-se que o trabalhador normativamente comprometido acredita ter obrigações e deveres morais para com a organização, devendo se comportar de forma que possa demonstrá-los” (Siqueira, 2001). A maneira apontada por Allen e Meyer (1996) para o empregado retribuir a organização é permanecer trabalhando para ela. CON se constitui, portanto, em crenças que integram a identidade do empregado num papel social de devedor perante a organização e que tem a obrigatoriedade de retribuir o benefício recebido.

\section{Percepção de reciprocidade organizacional}

No contexto organizacional, a norma de reciprocidade também seria evocada por um empregado ao representar mentalmente a organização como uma entidade social com a qual é possível entabular trocas sociais, aplicando às suas relações com a organização princípios semelhantes aos que usa para iniciar, manter e fortalecer relações na vida social. Percepção de reciprocidade organizacional (PRO) seria, segun- do Siqueira (1995), “um conjunto de crenças relacionadas à maneira como os empregados percebem a disposição da organização para emitir atos recíprocos” (p. 183). De acordo com essa perspectiva, o empregado desenvolve crenças sobre futuras retribuições organizacionais a determinados atos de trabalho, concebidos por ele como favores, benefícios ou ajuda à organização. Atos de ajuda à organização são aqueles ofertados informalmente por um empregado, sempre que ele percebe a necessidade de oferecer ao seu empregador uma quota extra de trabalho, extrapolando suas obrigações formais ou aplicando um esforço extra para resolver situações problemáticas e ou imprevistas que se apresentam em seu escopo de atuação na organização. Atos benéficos à organização e ofertados de forma espontânea constituem gestos de cidadania organizacional (Organ, 1990; Siqueira, 1995; 2003).

Segundo a percepção dos trabalhadores, tais atos os colocariam no papel de doadores e a organização no de receptora. A norma de reciprocidade permitiria ao empregado - que já foi doador para a organização no passado - acreditar que, no futuro, a organização devedora retribuiria seus gestos sociais de ajuda quando ocorressem situações problemáticas na vida pessoal e/ou profissional do empregado (Figura 4).

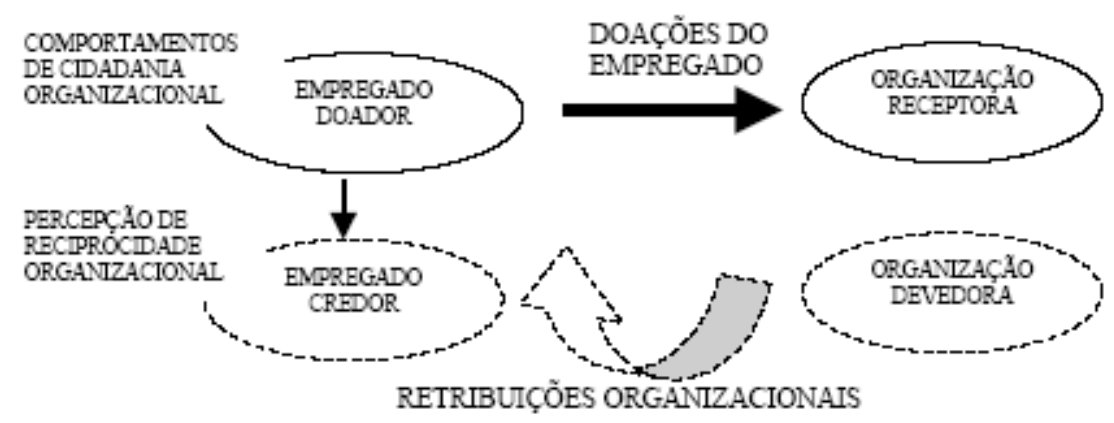

Figura 4. Percepção de reciprocidade organizacional como crenças do empregado credor. 
Ampliando a compreensão de PRO a partir de uma abordagem cognitivista, supõe-se que os papéis de doador e receptor, no passado, sejam reorganizados mentalmente pelo empregado para alterar a sua posição e a da organização na relação de troca social: de doador, o empregado se reposicionaria como credor e atribuiria, à organização, o papel de devedora. Tendo sido estruturada em forma de esquema mental, a norma de reciprocidade toma, então, o feitio de um padrão cognitivo que permite ao empregado nutrir expectativas de retribuição organizacional. Embora a norma de reciprocidade tenha sido teoricamente concebida no âmbito sociológico como um preceito moral para regulamentar o comportamento do receptor, dentro de uma visão psicológica cognitivista ela é vista como integrante de um esquema mental a partir do qual se organizam também expectativas de comportamento sobre a parte beneficiada numa troca social. Consoante estas noções, entende-se que PRO sejam crenças sobre retribuições da organização devedora nutridas pelo empregado ao assumir o papel de credor durante uma troca social. Sendo devedora social, a organização teria a obrigatoriedade de retribuir ao empregado doador os favores recebidos, ofertados na forma de gestos de cidadania organizacional.

\section{Hipóteses do estudo}

Neste estudo, o pressuposto básico assenta-se na noção de que um conjunto entrelaçado de conceitos sobre relações sociais formata um esquema mental matricial estruturado para norma de reciprocidade. A primeira hipótese assume que do esquema mental de reciprocidade reorganizado para as relações de troca entabuladas pelo empregado com a organização fazem parte três conjuntos distintos de crenças, denominadas por estudiosos do comportamento organizacional como percepção de suporte organizacional (PSO), comprometimento organizacional normativo (CON) e percepção de reciprocidade organizacional (PRO), apresentados e analisados anteriormente. Para evidenciar suporte empírico à suposição de serem PSO, CON e PRO conjuntos distintos de cognições, as frases que integram as respectivas medidas dos três conceitos deverão compor agrupamentos homogêneos de variáveis ao serem submetidas a análises fatoriais.

Como segunda hipótese, ainda visando a confirmar a identidade e distinção entre as três cognições que integram o esquema mental de reciprocidade durante uma troca social com a organização, PSO, CON e PRO deverão também apresentar relações significativas diretas, mas diferenciadas, com dois critérios afetivos do comportamento organizacional: um referente ao vínculo afetivo com o trabalho executado - satisfação no trabalho (STR) - e outro relativo à afetividade dirigida à organização - comprometimento organizacional afetivo (COA). Diversos pesquisadores já apresentaram evidências acerca das relações diretas entre essas variáveis (Bishop \& Scott, 2000; Eisenberger, Fasolo, \& Davis-La Mastro, 1990; Mathieu \& Zajac, 1990; Shore \& Tetrick, 1991; Wayne, Shore, \& Liden, 1997).

A terceira hipótese do estudo estabelece que os três componentes cognitivos (PSO, PRO e CON), que integram o es- quema mental de reciprocidade, são antecedentes de afetos dirigidos ao trabalho (STR) e à organização (COA), constituindo-se numa interação pós-cognitiva (Lazarus, 1982), segundo a qual uma base informacional sobre um dado objeto social, composta por elementos cognitivos, é necessária para que afetos sejam desenvolvidos frente ao objeto. As bases que sustentam este pressuposto são os resultados obtidos por Siqueira (1995), em um estudo em que foram apresentadas evidências acerca da relação pós-cognitiva entre cognições sobre a organização (percepção de suporte, percepção de reciprocidade e comprometimento organizacional calculativo) e vínculos afetivos com o trabalho (satisfação e envolvimento) e com a organização (comprometimento afetivo). Para confirmar a terceira hipótese, os três componentes cognitivos deverão prover índices de explicação significativos para a variância particular dos dois critérios afetivos escolhidos (STR e COA).

Como quarta hipótese do estudo, afirma-se que o papel de receptor na troca social com a organização (Figura 2) e que leva o empregado a nutrir crenças de PSO em seu esquema mental de reciprocidade, seja o componente cognitivo capaz de influenciar mais fortemente os seus vínculos afetivos com o trabalho (STR) e com a organização (COA). O teste empírico desta hipótese será realizado analisando-se as explicações providas particularmente por PSO, CON e PRO sobre variâncias de satisfação e comprometimento. A formulação desta suposição assenta-se também nos resultados de Siqueira $(1995 ; 2003)$ em que PSO foi o melhor antecedente cognitivo de vínculos afetivos com o trabalho e com a organização, durante o teste de um modelo pós-cognitivo para comportamentos de cidadania organizacional.

\section{Método}

\section{Participantes}

O estudo contou com a participação de 483 trabalhadores, $31,5 \%$ mulheres e $68,5 \%$ homens, com idade média de 26,48 anos $(D P=8,26)$, sendo a maioria solteira $(67,9 \%)$ e composta por universitários (78,5\%). As empresas eram públicas $(17,4 \%)$, ou particulares $(82,6 \%)$, com atividades nas áreas de serviços (46,21\%), de comércio (14,33\%), ou industrial $(39,46 \%)$; nas quais os participantes tinham estado trabalhando há 3,82 anos, em média ( $D P=1,79)$.

\section{Medidas das variáveis}

Do questionário utilizado fizeram parte cinco medidas e questões para caracterizar a amostra. As escalas empregadas foram:

1) Escala de Satisfação no Trabalho (EST), composta pelos 15 itens da versão reduzida (Siqueira, 1995), constituída por cinco sub-escalas que levaram os trabalhadores a indicar o grau de satisfação com os colegas de trabalho $(\alpha=$ $0,81)$, com o salário $(\alpha=0,90)$, a chefia $(\alpha=0,89)$, a natureza do trabalho $(\alpha=0,77)$ e as promoções $(\alpha=0,81)$.

2) Escala de Comprometimento Organizacional Afetivo (ECOA), em sua forma reduzida composta por cinco itens $(\alpha=0,93)$, desenvolvida por Siqueira (1995), que aferiu o grau 
de ligação afetiva dos participantes com as organizações em que trabalhavam.

3) Escala de Comprometimento Organizacional Normativo (ECON), composta por sete itens $(\alpha=0,86)$, construída e validada por Siqueira (2000), para aferir crenças dos trabalhadores acerca do débito moral diante da empresa empregadora.

4) Escala de Percepção de Suporte Organizacional (EPSO), em sua versão reduzida de 6 itens $(\alpha=0,86)$, originalmente elaborada por Eisenberger et al. (1986), adaptada e validada para o Brasil por Siqueira (1995).

5) Escala de Percepção de Reciprocidade (EPRO), que contém 18 frases com índice de precisão de 0,97, construída e validada por Siqueira (1995). No presente estudo foi utilizada sua forma reduzida, com seis frases $(\alpha=0,94)$.

Ao final do instrumento os participantes do estudo foram solicitados a informar seus dados pessoais (sexo, idade, estado civil e grau de instrução) e funcionais (tipo de empresa - pública ou particular - e tempo de serviço).

\section{Procedimento de coleta de dados}

Os questionários foram distribuídos e recolhidos nas empresas que autorizaram a coleta de dados ou em salas de aula, quando os participantes eram trabalhadores universitários. Para a coleta de dados nas empresas, os questionários foram entregues em envelopes fechados, constando no envelope o nome do pesquisador, seu telefone, o nome da universidade à qual se vinculava, a data da sua distribuição e de futuro recolhimento. A coleta de dados junto aos universitários que trabalhavam foi realizada em salas de aulas, após a autorização do professor e concordância dos alunos em participar do estudo.

\section{Análise dos dados}

O teste da primeira hipótese foi realizado sobre os 19 itens da EPSO, EPRO e ECON, aplicando-se o procedimento de análise dos componentes principais e solicitando-se a extração de três fatores através do método oblíquo (oblimin).

Para o teste da segunda hipótese foram criados escores, estimando a média dos pontos atribuídos pelos participantes aos itens de cada escala (EPSO, EPRO, ECON, EST e ECOA); e foram calculados coeficientes de correlação bivariada de Pearson para as relações entre eles.

A terceira hipótese do estudo foi testada calculando-se dois modelos de regressão múltipla (método enter), em que os escores de EPSO, EPRO e ECON foram posicionadas como variáveis independentes e os de EST e ECOA participaram como as variáveis dependentes.

Modelos de regressão múltipla envolvendo o método stepwise permitiram testar a quarta hipótese deste estudo. Escores de EPSO, EPRO e ECON figuraram como variáveis independentes; enquanto os de ECOA e dos cinco fatores de EST como as variáveis dependentes dos seis modelos.

\section{Resultados e discussão}

Os primeiros resultados obtidos neste estudo revelaram que o conjunto de 19 itens combinados de EPSO, EPRO e
ECON formou três componentes principais com valores-critério (eigenvalues) superiores a 1,67 e explicou 70,84\% da variância total. A rotação oblíqua (oblimin) apontou três fatores compostos, respectivamente, por seis itens da EPRO no primeiro fator, sete itens da ECON no segundo fator, e seis itens da EPSO no terceiro fator. A fidedignidade das escalas (coeficiente alfa de Cronbach) foi de: 0,97 para a EPRO; 0,93 para a EPSO; e 0,84 para a ECON (Tabela 1).

Esses resultados trazem evidências para a primeira hipótese deste estudo, demonstrando que, pelo fato dos itens das medidas formarem fatores oblíquos distintos - os quais correspondem a agrupamentos separados de variáveis, mas correlacionados entre si -, os três conceitos cognitivos representados por elas poderiam ser considerados como tendo identidades próprias, mas, ao mesmo tempo, sendo integrantes de um esquema mental de reciprocidade.

Os valores apresentados na última coluna da Tabela 2 para as cinco medidas usadas neste estudo revelaram tratarse de instrumentos confiáveis, que apresentam índices de fidedignidade (coeficiente alfa de Cronbach) entre 0,84 e 0,97; assegurando maior tranqüilidade quanto aos resultados obtidos neste estudo.

A segunda hipótese do estudo foi também confirmada, visto terem sido obtidos valores distintos para índices de correlação significativos entre os três componentes cognitivos do esquema mental de reciprocidade e os dois critérios afetivos do comportamento organizacional (Tabela 2). PSO foi o componente cognitivo mais fortemente associado a STR e COA, seguido por CON e PRO que produziram correlações inferiores. Estes resultados já sinalizam ser PSO, crenças nutridas pelo empregado receptor, o componente cognitivo mais provável de ter maiores influências sobre STR e COA. Os três componentes cognitivos também se correlacionaram positiva e significativamente entre si, revelando serem três conjuntos de crenças associados, embora representantes de conceitos teóricos distintos da literatura do comportamento organizacional e supostos de serem nutridos segundo os papéis sociais do empregado receptor, devedor ou credor.

Dois modelos de regressão múltipla, calculados pelo método enter, estão contidos na Tabela 3. Através destes resultados pode-se verificar que os três componentes cognitivos do esquema mental de reciprocidade conseguiram explicar 51,6\% da variância de comprometimento afetivo $\left(R^{2}=0,516 ; F_{(3,475)}=171,017 ; p<0,01\right)$. O segundo modelo de regressão informa que PSO, CON e PRO proveram índices de explicação significativos para satisfação geral no trabalho, explicando 45,8\% de sua variância $\left(R^{2}=0,458 ; F_{(3,474)}=135,511\right.$; $p<0,01)$. Diante destes resultados, fica evidente ser o esquema mental de reciprocidade, aqui representado nos dados do estudo por três componentes cognitivos - PSO, CON e PRO - um forte antecedente de futuros vínculos afetivos do empregado com a organização empregadora (COA) e com o trabalho executado (STR). Portanto, para desenvolver elos afetivos com a organização e o trabalho, é necessário o empregado receptor manter crenças de ser ela (a organização) uma doadora (PSO), se identificar como devedor da organiza- 
Tabela 1

Cargas fatoriais na matriz padrão após rotação oblíqua dos itens integrantes da EPRO, ECON e EPSO.

\begin{tabular}{|c|c|c|c|}
\hline ITENS DAS ESCALAS & $\begin{array}{l}\text { Fator } 1 \\
\text { EPRO }\end{array}$ & $\begin{array}{l}\text { Fator } 2 \\
\text { ECON }\end{array}$ & $\begin{array}{c}\text { Fator } 3 \\
\text { EPSO }\end{array}$ \\
\hline \multicolumn{4}{|c|}{$\begin{array}{l}\text { A empresa onde trabalho costuma... } \\
1=\text { não dar recompensas } / 5=\text { dar recompensas excelentes }\end{array}$} \\
\hline Aos empregados criativos no trabalho & 0,95 & & \\
\hline Aos empregados esforçados no trabalho & 0,94 & & \\
\hline Aos empregados que se preocupam com a empresa & 0,93 & & \\
\hline Aos empregados que defendem os objetivos da empresa & 0,92 & & \\
\hline Aos empregados competentes no trabalho & 0,92 & & \\
\hline Aos empregados que procuram fazer a empresa crescer & 0,87 & & \\
\hline \multicolumn{4}{|l|}{$1=$ discordo totalmente $/ 5=$ concordo totalmente } \\
\hline Seria desonesto de minha parte ir trabalhar para outra empresa agora. & & 0,84 & \\
\hline Eu seria injusto com essa empresa se pedisse demissão agora e fosse trabalhar para outra. & & 0,82 & \\
\hline É a gratidão por essa empresa que me mantém ligado a ela. & & 0,78 & \\
\hline É minha obrigação continuar trabalhando para essa empresa & & 0,77 & \\
\hline Continuar trabalhando nessa empresa é uma forma de retribuir o que ela já fez por mim. & & 0,62 & \\
\hline Nesse momento essa empresa precisa dos meus serviços. & & 0,52 & \\
\hline Essa empresa já fez muito por mim no passado & & 0,50 & \\
\hline \multicolumn{4}{|l|}{ 1=discordo totalmente $/ 7=$ concordo totalmente } \\
\hline Essa empresa realmente se preocupa com meu bem-estar. & & & $-0,88$ \\
\hline Essa empresa está pronta a me ajudar quando eu precisar de um favor especial. & & & $-0,87$ \\
\hline Essa empresa se preocupa com minha satisfação no trabalho. & & & $-0,82$ \\
\hline É possível obter ajuda dessa empresa quando tenho um problema. & & & $-0,81$ \\
\hline $\begin{array}{l}\text { Essa empresa estaria disposta a ampliar suas instalações para me ajudar a utilizar as minha } \\
\text { melhores habilidades no desempenho do meu trabalho. }\end{array}$ & & & $-0,81$ \\
\hline Essa empresa tenta fazer com que meu trabalho seja o mais interessante possível. & & & $-0,76$ \\
\hline Eigenvalue & 9,19 & 2,61 & 1,67 \\
\hline \% de variância & 48,38 & 13,72 & 8,75 \\
\hline Alfa de Cronbach & 0,97 & 0,84 & 0,93 \\
\hline $\mathrm{N}^{\mathrm{o}}$ de itens & 6 & 7 & 6 \\
\hline
\end{tabular}

Tabela 2

Coeficientes de correlação (Pearson) relativos aos escores das variáveis do estudo

\begin{tabular}{|c|c|c|c|c|c|c|c|}
\hline Variáveis & EPSO & ECON & EPRO & EST & $\begin{array}{l}\text { Médias } \\
\text { (escala) }\end{array}$ & $\mathrm{DP}$ & $\begin{array}{c}\text { Precisão das } \\
\text { medidas }\end{array}$ \\
\hline Escala de percepção de suporte organizacional (EPSO) & - & & & & $\begin{array}{c}4,23 \\
(1 \text { a } 7)\end{array}$ & 1,56 & 0,93 \\
\hline Escala de comprometimento organizacional normativo (ECON) & $0,51 * *$ & - & & & $\begin{array}{c}2,37 \\
(1 \text { a } 5)\end{array}$ & 0,79 & 0,84 \\
\hline Escala de percepção de reciprocidade organizacional (EPRO) & $0,61 * *$ & $0,40 * *$ & - & & $\begin{array}{c}3,10 \\
(1 \text { a } 6)\end{array}$ & 1,49 & 0,97 \\
\hline Escala de satisfação no trabalho (EST) & $0,66 * *$ & $0,49 * *$ & $0,44^{* *}$ & - & $\begin{array}{c}4,37 \\
(1 \text { a } 7)\end{array}$ & 0,95 & 0,90 \\
\hline Escala de comprometimento organizacional afetivo (ECOA) & $0,71 * *$ & $0,44 * *$ & $0,51 * *$ & $0,68 * *$ & $\begin{array}{c}3,32 \\
(1 \text { a } 5)\end{array}$ & 0,95 & 0,94 \\
\hline
\end{tabular}

** $p<0,01$

ção e acreditar estar moralmente em débito com ela (CON) e, finalmente, que em situações nas quais o empregado se posicionar como doador, a organização deverá ser mentalmente representada como um ator social que retribui ofertas espontâneas de seus colaboradores (PRO). Os resultados destas análises tendem, portanto, a sustentar a veracidade da terceira hipótese deste estudo e a corroborar resultados contidos na literatura, visto que já existem evidências em estudos anteriores (Lazarus, 1982; Siqueira, 1995) sobre a capacidade das cognições proverem explicações para variáveis afetivas em modelos pós-cognitivos.

As análises para testar a quarta hipótese foram feitas com modelos de regressão múltipla utilizando-se o método stepwise. Neste caso, os escores da ECOA e os cinco escores 
Tabela 3

Dois modelos de regressão múltipla relativos aos dois critérios afetivos

\begin{tabular}{llccc}
\hline \multirow{2}{*}{ Modelos } & Variáveis dependentes & $R^{2}$ modelo & $\begin{array}{c}\text { Variáveis } \\
\text { independentes }\end{array}$ & $\begin{array}{c}\text { Betas } \\
\text { padronizados }\end{array}$ \\
\hline Modelo 1 & Comprometimento organizacional afetivo & $0,516^{* *}$ & PSO & $0,606^{* *}$ \\
& & & CON & 0,066 \\
Modelo 2 Satisfação no trabalho & & PRO & $0,116^{*}$ \\
& & $0,458^{* *}$ & PSO & $0,545^{* *}$ \\
& & & CON & $0,172^{* *}$ \\
\hline
\end{tabular}

Nota. PSO = Percepção de Suporte Organizacional; COM = Comprometimento Organizacional Normativo; PRO = Percepção de Reciprocidade Organizacional.

$* * p<0,01$

nos fatores da EST foram colocados como variáveis dependentes, enquanto os escores da EPSO, da ECON e da EPRO foram posicionados como variáveis independentes em seis modelos de regressão, nos quais puderam ser identificados os percentuais de explicação providos individualmente por três componentes cognitivos (Tabela 4).

Os resultados contidos na Tabela 4 revelaram que os três componentes cognitivos supostos de integrarem o esquema mental de reciprocidade na troca social entabulada pelo empregado com a organização conseguiram prover explicações significativas para afetos dirigidos à organização e ao trabalho. Ficou constatado também ser PSO o componente cognitivo capaz de prover maiores explicações para comprometimento afetivo e os cinco fatores de satisfação no trabalho, confirmando, portanto a quarta hipótese do estudo.

No primeiro modelo, calculado para COA, PSO explicou $50,7 \%$ de sua variância $\left(R_{p}^{2}=0,507 ; F_{(1,477)}=490,23 ; p<0,01\right)$ enquanto PRO contribui com apenas $0,9 \%\left(R_{p}^{2}=0,009\right.$; $\left.F_{(1,476)}=9,253 ; p<0,05\right)$. O vínculo normativo com a organização (CON) não foi retido no modelo. A quarta hipótese deste estudo, no que concerne à COA, foi confirmada, indicando que comprometimento organizacional afetivo, ou o desejo de permanecer trabalhando para a organização, conforme definição de Allen e Meyer (1996), constitui-se em uma conseqüência do quanto o empregado receptor, durante uma troca social, percebe a empresa em que trabalha como uma fonte de apoio ou suporte social (organização doadora).

A variância do fator satisfação com colegas foi explicada em $12,7 \%\left(R_{m}^{2}=0,127 ; F_{(1,476)}=69,427 ; p<0,01\right)$, através de um modelo composto apenas por PSO. Neste caso, o contentamento com os pares de trabalho tende a ser influenciado apenas por cognições do empregado receptor. Portanto, crenças sobre obrigatoriedade de retribuir a organização, nutridas por empregados no papel de devedor (CON) e crenças sobre retribuições organizacionais mantidas quando o empregado se posiciona no esquema mental de reciprocidade como credor (PRO), não influenciam significativamente a satisfação com os colegas de trabalho.
Satisfação com a chefia teve $28,4 \%$ de sua variância explicada por dois componentes cognitivos, observandose uma forte participação de PSO que contribuiu com 27,8\% $\left(R_{p}^{2}=0,278 ; F_{(1,477)}=183,602 ; p<0,01\right)$ e CON com $0,6 \%\left(R_{p}^{2}\right.$ $\left.=0,006 ; F_{(1,476)}=4,157 ; p<0,05\right)$. Estes resultados confirmam que especialmente crenças do empregado receptor, e menos as que ele mantém como devedor, influenciam a afetividade pelas chefias no contexto organizacional. Crenças de empregado credor, representadas no estudo por PRO, não participaram do modelo de regressão múltipla para satisfação com a chefia.

Satisfação com o salário teve sua variância explicada em $18,2 \%$ por dois dos três componentes cognitivos estudados, sendo $15,8 \%\left(R_{p}^{2}=0,158 ; F_{(1,477)}=89,686 ; p<0,01\right)$ produzidas por PSO e 2,3\% por $\operatorname{CON}\left(R_{p}^{2}=0,023 ; F_{(1,476)}=13,634 ; p\right.$ $<0,01)$. Diante destes resultados, fica confirmada a influência exercida por crenças do empregado receptor e devedor sobre o seu contentamento com o salário. Cabe observar que crenças de empregado credor não foram retidas no modelo.

O modelo calculado para satisfação com promoções foi o único que manteve os três componentes cognitivos. Neste caso, a explicação foi da ordem de $46 \%$, sendo $43,30 \%$ pertencente a PSO $\left(R_{p}^{2}=0,433 ; F_{(1,477)}=364,640 ; p<0,01\right)$, um percentual bem menor a CON, na ordem de $1,8\left(R_{p}^{2}=0,018\right.$; $\left.F_{(1,476)}=15,227 ; p<0,01\right)$, e outro percentual inferior a $1 \%$ provido por PRO $\left(R_{p}^{2}=0,009 ; F_{(1,475)}=8,275 ; p<0,01\right)$. Conforme estes resultados, acreditar que a empresa seja uma fonte de doação torna-se um forte elemento cognitivo capaz de influenciar positivamente satisfação com as promoções de pessoal desenhadas por organizações, enquanto influências menores poderão advir de crenças nutridas por empregados devedores e credores.

O último modelo, calculado para satisfação com o próprio trabalho, também revelou que PSO explicou a maior parcela de variância deste fator, contribuindo com $27,1 \%\left(R_{p}^{2}=\right.$ 0,$\left.271 ; F_{(1,477)}=177,360 ; p<0,01\right)$, enquanto CON ofereceu apenas $0,8 \%$ de explicação $\left(R_{p}^{2}=0,008 ; F_{(1,476)}=5,594 ; p<\right.$ $0,05)$. Novamente, crenças de empregado receptor mostra- 
Tabela 4

Regressão múltipla stepwise sobre comprometimento afetivo (COA) e cinco fatores de satisfação no trabalho (STR)

\begin{tabular}{|c|c|c|c|c|c|}
\hline $\begin{array}{c}\text { Variáveis } \\
\text { dependentes }\end{array}$ & $\begin{array}{c}\text { Variáveis } \\
\text { independentes }\end{array}$ & Passos & $\begin{array}{c}R^{2} \\
\text { parciais }\end{array}$ & $\begin{array}{c}R^{2} \\
\text { modelo }\end{array}$ & $\begin{array}{c}\text { Betas } \\
\text { padronizados }\end{array}$ \\
\hline Comprometimento & PSO & 1 & $0,507 * *$ & \multirow[b]{2}{*}{$0,516 * *$} & $0,637 * *$ \\
\hline organizacional afetivo & $\mathrm{PRO}$ & 2 & $0,009 * *$ & & $0,123 * *$ \\
\hline Satisfação com colegas & PSO & 1 & $0,127 * *$ & $0,127 * *$ & $0,357 * *$ \\
\hline Satisfação com chefia & PSO & 1 & $0,278 * *$ & \multirow[t]{2}{*}{$0,284 * *$} & $0,476 * *$ \\
\hline \multirow[t]{2}{*}{ Satisfação com salário } & $\begin{array}{l}\text { CON } \\
\text { PSO }\end{array}$ & $\begin{array}{l}2 \\
1\end{array}$ & $\begin{array}{l}0,006 * \\
0,158 * *\end{array}$ & & $\begin{array}{l}0,094^{*} \\
0,300^{* *}\end{array}$ \\
\hline & $\mathrm{CON}$ & 2 & $0,023 *$ & $0,182 * *$ & $0,182 * *$ \\
\hline Satisfação com promoções & $\begin{array}{l}\text { PSO } \\
\text { CON } \\
\text { PRO }\end{array}$ & $\begin{array}{l}1 \\
2 \\
3\end{array}$ & $\begin{array}{l}0,433 * * \\
0,018 * * \\
0,009 * *\end{array}$ & $0,460 * *$ & $\begin{array}{l}0,504 * * \\
0,146 * * \\
0,123 * *\end{array}$ \\
\hline \multirow[t]{2}{*}{ Satisfação com o próprio trabalho } & PSO & 1 & $0,271 * *$ & \multirow[t]{2}{*}{$0,280 * *$} & $0,462 * *$ \\
\hline & $\mathrm{CON}$ & 2 & $0,008 *$ & & $0,109 *$ \\
\hline
\end{tabular}

Nota. PSO = Percepção de Suporte Organizacional; CON = Comprometimento Organizacional

Normativo; PRO = Percepção de Reciprocidade Organizacional.

** $p<0,01 ; * p<0,05$

ram-se capazes de afetar positivamente mais um fator de satisfação, revelando que acreditar em doações organizacionais pode ser uma cognição desencadeadora de afetividade por trabalho realizado. Mais uma vez, crenças de empregado devedor contribuíram em menor escala e crenças de empregado credor foram mantidas fora do modelo. Os resultados obtidos do teste da quarta hipótese encontram sustentação na literatura, visto que confirmam achados de Siqueira (1995; 2003) quando a autora demonstrou ser PSO um forte antecedente de satisfação e comprometimento.

\section{Conclusões}

As análises processadas durante este estudo produziram resultados que comprovaram as quatro hipóteses formuladas. As suposições sobre o esquema mental para a norma de reciprocidade apresentadas neste estudo podem ter uma importante contribuição para futuras pesquisas do comportamento organizacional, visto que através delas é possível articular contribuições sociológicas defendidas por pensadores sociais como Blau (1964) e Gouldner (1960) a proposições cognitivistas acerca da representação mental do conhecimento, especialmente aquelas que contêm noções sobre organização mental através de esquemas (Sternberb, 2000).

Os resultados que demonstraram a identidade dos três conceitos cognitivos, tidos como integrantes do esquema mental de reciprocidade na permuta social entabulada pelo empregado com a organização, trazem evidências que permi- tem a utilização das escalas analisadas em futuras investigações sobre o tema reciprocidade. Tal conclusão parece pertinente, não só porque as escalas se mostraram válidas, mas também fidedignas, na medida em que seus respectivos itens compuseram fatores homogêneos e seus índices de confiabilidade se situaram acima de 0,80; valor considerado satisfatório para medidas utilizadas em pesquisas científicas (Pasquali, 1997).

Relações positivas e significativas observadas no estudo entre os três componentes do esquema mental de reciprocidade indicam que os mesmos são altamente interdependentes, sugerindo que os papéis sociais de empregado receptor, devedor e doador podem estar formatados mentalmente em um mesmo esquema mental, cuja ativação ou evocação dependerá das circunstâncias em que o empregado se encontra em sua dinâmica de vida pessoal e ou profissional. Futuras pesquisas seriam necessárias para reafirmar e consolidar os achados deste estudo, através de investigações que conseguissem detectar no momento da coleta de dados em qual papel o empregado se posiciona, permitindo identificar se ele tem, no momento, mais ativados os componentes cognitivos de receptor e devedor ou aquele em que ele se posiciona como antigo doador e atual credor da organização.

Uma questão intrigante, que merece análise, é a forte influência de PSO sobre a afetividade no trabalho, aqui representada por satisfação e comprometimento afetivo. Acreditase que PSO, ou um conjunto de crenças nutridas pelo empregado em seu papel de devedor da organização doadora, seja 
resultante de convicções culturalmente transmitidas, quando se formata mentalmente o papel das empresas como atores sociais detentores de amplos recursos, aos quais o trabalhador tem acesso ao se tornar seu colaborador. Neste sentido, ao ingressar em uma empresa o indivíduo a representa mentalmente como uma possível fonte de apoio e suporte à qual está ligado por laços de trabalho. A seguir, assume o papel social de receptor, em decorrência de informações que capta no meio organizacional acerca de doações ou suportes que a empresa costuma oferecer a seus colaboradores por intermédio de políticas de gestão de pessoas. É possível que pelo fato de empresas serem concebidas culturalmente como entidades detentoras de recursos e que estes sejam, em parte, distribuídos aos colaboradores, eles entendam ser beneficiários em uma troca social, iniciada pela empresa ao ofertar benefícios de forma genérica a todos, ou especiais a determinadas pessoas que se destacam. Todas estas conjecturas merecem investigações futuras.

Entende-se que os três conceitos psicossociais analisados, PSO, CON e PRO constituam conceitos configurados mentalmente por pesquisadores, e não por trabalhadores. Assim sendo, não se pode afirmar que os mesmos integrem o esquema mental de reciprocidade dos trabalhadores como conceitos. A sua integração a este esquema se faz, possivelmente, através de conexões mentais complexas, que ativam conjuntos diversos de crenças, provavelmente organizadas mentalmente em forma de um arranjo simbólico que se conecta à representação mental da organização. $\mathrm{O}$ que se tentou demonstrar neste estudo foi a possibilidade desses três conceitos teóricos serem compostos por conjuntos particulares de crenças, os quais podem ser individualmente ou conjuntamente ativados quando o empregado se situa como receptor, devedor ou doador na permuta social com a organização. Discussões sobre este aspecto devem merecer a atenção de estudiosos.

Sintetizando as análises conceituais e os resultados empíricos deste estudo, é possível aceitar como pertinente a existência de um esquema mental de reciprocidade, cuja função psicológica seria de permitir ao trabalhador manusear mentalmente informações sobre seus papéis sociais de receptor e devedor quando se relaciona com uma organização numa interação de troca social. Este esquema mental, por sua vez, amplia-se quando o empregado assume o papel de doador, oferecendo gestos de colaboração espontânea à organização e desenvolvendo expectativas acerca de sua reciprocidade, lembrando-se com maior clareza de ter sido doador e de ter a organização o dever de retribuir quando vivencia situações problemáticas para as quais necessitaria de apoio organizacional.

Como conclusão prescritiva, sugere-se que gerentes atentem para a importância de seus papéis como executores de políticas organizacionais, visto que no esquema mental de reciprocidade dos trabalhadores a noção de organização doadora é estruturada a partir de atos gerenciais, sendo essas ações o início da troca social que, por sua vez, levam empregados a se posicionarem como beneficiários e a acreditar no suporte organizacional, a se perceberem como devedores e se comprometerem normativamente com a organização, resultando em vínculos afetivos com o trabalho e com a organização. Acrescente-se a estas prescrições as evidências de estudos anteriores (Siqueira, 1995; 2003) em que cognições sobre relações de troca social com organizações antecedem satisfação e comprometimento que, por sua vez, levam os trabalhadores a se comportar espontaneamente a favor da empresa, oferecendo gestos de cidadania organizacional. Portanto, os atos gerenciais podem afetar toda uma cadeia psicossocial, ao influenciar a estruturação dos componentes de um esquema mental que afetam a afetividade no trabalho e estes, por sua vez, podem alterar padrões de comportamento de toda uma corporação.

\section{Referências}

Allen, N. J., \& Meyer, J. P. (1996). Affective, continuance, and normative commitment to the organization: an examination of construct validity. Journal of Vocational Behavior, 49, 252-276.

Becker, H. (1956). Man in reciprocity. Nova York: Prager.

Bishop, J. W., \& Scott, K. D. (2000). Organizational and team commitment in a team environment. Journal of Applied Psychology, 85, 439-450.

Blau, P. M. (1964). Exchange and power in social life. Nova York: Wiley.

Collins, A. M., \& Quillan, M. R. (1969). Retrieval time from semantic memory. Journal of Verbal Learning and Verbal Behavior, 9, 240-248.

Eisenberger, R., Fasolo, P., \& Davis-La Mastro, V. (1990). Perceived organizational support and employee diligence, commitment, and innovation. Journal of Applied Psychology, 75, 51-59.

Eisenberger, R., Huntington, R., Hutchison, S., \& Sowa, D. (1986). Perceived organizational support. Journal of Applied Psychology, 71, 500-507.

Eysenck, M. W., \& Keane, M. T. (1994). Psicologia cognitiva: um manual introdutório. Porto Alegre: Artes Médicas.

Gibbs, J. P. (1989). Control: Sociology's central notion. Urbana: University of Illinois Press.

Gouldner, A. W. (1960). The norm of reciprocity: a preliminary statement. American Sociological Review, 25, 161-178.

Gundlach, G., Achrol, R. S., \& Mentzer, J. T. (1995). The structure of commitment in exchange. Journal of Marketing, 59, 78-92.

Homans, G. C. (1958). Social behavior as exchange. American Journal of Sociology, 63, 597-606.

Konovsky, M. A., \& Pugh, S. D. (1994). Citizenship behavior and social exchange. Academy of Management Journal, 37, 656-669.

Lazarus, R. S. (1982). Thoughts on the relation between emotion and cognitions. American Psychologist, 37, 1019-1024.

Malinovski, B. (1922). Argonauts of the Western Pacific. Londres: Routledge \& Kegan Paul.

Mathieu, J. E., \& Zajac, D. M. (1990). A review and meta-analysis of the antecedents, correlates, and consequences of organizational commitment. Psychological Bulletin, 108, 171-194.

Nova, S. V. (2000). Introdução à sociologia. São Paulo: Atlas.

Organ, D. W. (1990). The motivational basis of organizational citizenship behavior. In B. M. Staw \& L. L. Cunnings (Orgs.), Research in Organizational Behavior (pp. 442-472). Stanford: Jai Press.

Pasquali, L. (1997). Psicometria: teoria e aplicações. Brasília: Editora Universidade de Brasília.

Shore, L. M., \& Tetrick, L. E. (1991). A construct study of the survey of perceived organizational support. Journal of Applied Psychology, 76, 637-643. 
Siqueira, M. M. M. (1995). Antecedentes de comportamentos de cidadania organizacional: a análise de um modelo pós-cognitivo. Tese de doutorado não-publicada, Universidade de Brasília, Brasília.

Siqueira, M. M. M. (2000). Análises de três medidas de comprometimento organizacional: afetivo, calculativo e normativo [Resumo]. In Instituto Brasileiro de Avaliação Psicológica (Org.), VIII Conferência Internacional de Avaliação Psicológica. Resumos (p. 40-41). Belo Horizonte: Autor.

Siqueira, M. M. M. (2001). Comprometimento organizacional afetivo, calculativo e normativo: evidências acerca da validade discriminante de três medidas brasileiras. [Trabalho completo]. In Associação Nacional de Pós-Graduação em Administração (Org.), XXV EnANPAD. Anais do EnANPAD 2001 (CDROM). Campinas: Autor.

Siqueira, M. M. M. (2003). Proposição e análise de um modelo para comportamentos de cidadania organizacional. Revista de Administração Contemporânea, 7, 165-184.

Sternberg, R. J. (2000). Psicologia cognitiva. Porto Alegre: Artes Médicas.

Wayne, S. J., Shore, L. M., \& Liden, R. L. (1997). Perceived organizational support and leader-member exchange: a social exchange perspective. Academy of Management Journal, 10, 82-111.

Wiener, Y. (1982). Commitment in organizations: a normative view. Academy of Management Review, 7, 418-428.

Mirlene Maria Matias Siqueira, doutora em Psicologia pela Universidade de Brasília, é professora na Universidade Metodista de São Paulo. Endereço para correspondência: Rua Myriam Dora Rossi, 100, Apto. 84; Chácara Inglesa, São Bernardo do Campo, SP; CEP 09726-100. Tel.: (11) 4337-6650. Fax: (11) 4390-8273. Email:mirlenesiqueira@uol.com.br 